\title{
Analisis Dampak Sukuk pada Perekonomian Nasional di Tengah Wabah Covid 19
}

\author{
Binti Nur Asiyah \\ IAIN Tulungagung \\ binti.advan@gmail.com \\ Indah Nur Aini \\ IAIN Tulungagung \\ indahnur095@gmail.com \\ Rama Prasetya Mahardika \\ IAIN Tulungagung \\ ramapras19@gmail.com \\ Lyliya Nurul Laili \\ IAIN Tulungagung \\ nurullaili209@gmail.com
}

\begin{abstract}
Sukuk is a form of investment that has an impact on the national economy which is currently weakening due to the Covid-19 pandemic. Covid 19 has had an impact on the faltering of the people's economy from business to financial institutions (sharia and conventional). The state has the need to fulfill the state budget in order to address the problem of the impact of covid 19 quickly. This paper is intended to analyze the impact of sukuk on economic growth during the covid pandemic 19. The process of collecting data is done by analyzing data observed through OJK statistics and collecting various information related to covid-19 and the data are analyzed qualitatively. Based on the results of the study it was found that Sukuk became a source of funds for the government to finance development, thus creating new jobs for the community in the long run. Sukuk provide benefits for the liquidity of Islamic financial institutions due to the impact of covid 19, and also investment facilities for the community.
\end{abstract}

Key Words: Impact; Sukuk; national economiy; Covid-19.

\begin{abstract}
Abstrak: Sukuk termasuk bentuk investasi yang memberikan dampak bagi perekonomian nasional yang saat ini melemah karena adanya pandemi Covid-19.Covid 19 telah memberikan dampak bagi tersendatnya perekonomian masyarakat mulai bisnis hingga lembaga keuangan (syariah dan konvensional). Negara memiliki kebutuhan pemenuhan APBN guna menjawab masalah dari dampak covid 19 secara cepat. Paper ini dimaksudkan untuk menganalisis dampak sukuk bagi pertumbuhan ekonomi di masa pandemi covid 19. Proses pengumpulan data dilakukan dengan cara menganalisis data yang diobservasi melalui statistik OJK dan mengumpulkan


berbagai informasi terkait covid-19 dan data dianalisis secara kualitatif. Berdasarkan hasil pengkajian diperoleh bahwa Sukuk menjadi sumber dana bagi pemerintah untuk membiayai pembangunan, sehingga menciptakan lapangan kerja baru bagi masyarakat dalam jangka panjangnya. Sukuk memberikan kemanfaatan bagi likuiditas lembaga keuangan syariah akibat dampak covid 19, dan juga sarana investasi bagi masyarakat..

Kata Kunci : $\quad$ Dampak; Sukuk; Perekonomian Nasional; Covid-19.

\section{PENDAHULUAN}

Bursa efek syariah menjadi sumber modal bagi kebutuhan suatu industri. Tidak terkecuali adalah Negara yang membutuhkan sejumlah dana guna membiayai Anggaran Pendapatan dan Belanja Negara (APBN). Guna memenuhi kebutuhan tersebut negara menawarkan Sukuk kepada masyarakat yang memiliki kelebihan dana untuk menginvestasikan kepada negara melalui Sukuk. Kata sukuk memiliki arti sertifikat atau dokumen, yang berasal dari kata 'sakk', dalam peristilahan ekonomi jamak dari kata sakk berarti legal instrument, deed atau check. Saat ini sukuk yang banyak diterbitkan berdasar pada akad ijarah atau sewa, dimana hasil investasi akan dihasilkan berdasarkan arus pembayaran sewa tersebut. Tidak hanya itu saja sukuk diterbitkan dalam bentuk akad syariah.Sukuk diterbitkan oleh Special Purpose Vehicle (SPV). Akad yang digunakan untuk sukuk biasanya menggunakan akad ijarah, mudharabah, murabahah, musyarakah, istishna, dan juga salam.

Keadaan seperti saat ini,dengan adanya pandemi covid-19 berimbas juga pada penerbitan sukuk. Dapat diketahui covid-19 merupakan virus RNA strain tunggal positif, berkapsul dan tidak bersegmen. Coronavirus tergolong ordo Nidovirales, keluarga Coronaviridae. Struktur coronavirus membentuk struktur seperti kubus dengan protein $S$ berlokasi di permukaan virus. Protein $S$ atau spike protein merupakan salah satu protein antigen utama virus dan merupakan struktur utama untuk penulisan gen. Protein S ini berperan dalam penempelan dan masuknya virus kedalam sel host (interaksi protein $\mathrm{S}$ dengan reseptornya di sel inang). Coronavirus bersifat sensitif terhadap panas dan secara efektif dapat diinaktifkan oleh desinfektan mengandung klorin, pelarut lipid dengan suhu $56^{\circ} \mathrm{C}$ selama 30 menit, eter, alkohol, asam perioksiasetat, detergen non-ionik, formalin, oxidizing agent dan kloroform. Klorheksidin tidak efektif dalam menonaktifkan virus.

Dengan adanya virus ini, sukuk mengalami penurunan terbukti dari penarikan lelang SBSN atau sukuk yang dilakukan oleh pemerintah. Dari lelang tersebut pemerintah mendapatkan dana sebesar 6,6 triliun. Hal tersebut masih kurang dari target yang ditetapkan namun angka ini cukup tinggi mengingat kelesuan ekonomi yang terjadi saat ini. Dana yang terkumpul dari lelang itu akan dipegang pemerintah untuk kemudian disalurkan ke dunia usaha melalui kredit khusus yang dibuat semurah mungkin. Hal ini bertujuan untuk mengurangi PHK yang banyak terjadi akibat perusahaan kekurangan cashflow dan likuiditas keuangan. Dari pemaparan tersebut dapat ditarik kesimpulan bahwa sukuk cukup berpengaruh bagi perekonomian saat terjadi pandemi covid 19 mengingat investasi sukuk memiliki resiko yang kecil. 
Kemudian untuk menanggapi hal ini penulis mengambil tema analisis dampak sukuk pada perekonomian nasional di tengah wabah covid 19. Hal ini bertujuan untuk memudahkan masyarakat memahami pentingnya sukuk negara bagi ketermanfaatan bagi pembangunan maupun penanganan virus corona.

\section{METODE PENELITIAN}

Metode yang digunakan dalam penulisan paper ini menggunakan pendekatan deskriptif kualitatif, dengan mendeskripsikanpaper ini bersumber dari buku, jurnal, serta data dari OJK yang di dalamnya membahas berbagai masalah mengenai bagaimana pengaruh sukuk pada perekonomian Nasional ditengah wabah covid-19.

\section{SUKUK \\ Pengertian}

Sukuk secara etimologi berasal dari bahasa arab, sukuk berasal dari kata 'sakk' yang artinya sertifikat atau dokumen. Kegiatan trasaksi dan laporan yang terjadi dicatat dalam buku disebut dengan sakk ${ }^{1}$.Menurut syaria standard no.17 tentang investmen sukuk, Acounting and Auditing Organization for Islamic Institution (AAOIFII) mendefinisikan sukuk sebagai surat berharga yang dapat dibuat bukti kepemilikan atas aset berwujud ${ }^{2}$. Peraturan Badan Pengawasan Pasar Modal da Lembaga Keuangan (BAPEPAM-LK) Nomor IX.A.13 memberikan definisi sukuk ialah efek syariah berupa sertifikat atau sertifikat yang memiliki nilai yang sama dan mewakilibagian yang tidak tertentu (tidak terpisahkan atau tidak terbagi) atas: aset berwujud, nilai manfaat atas aset berwujud dan jasa. 3

Berdasarkan Fatwa Dewan Syariah Nasional Majelis Ulama Indonesia (DSN-MUI) No. 32/DSN-MUI/IX/2002 surat berharga syariah adalah surat berharga jangka panjang berdasarkan prinsip syariah yang dikeluarkan oleh emiten kepada pemegang obligasi syariah yang mewajibkan emiten untuk membayar pendapatan kepada pemegang obligasi syariah. Sedangkan berdasarkan fatwa DSN-MUI No. 69/DSN-MUI/VI/2008 Surat Berharga Syariah Negara (SBSN) atau Sukuk Negara adalah surat berharga negara yang dikeluarkan berdasarkan prinsip syariah, yang digunakan sebagai bukti atas bagian penyertaan terhadap asset SBSN baik dalam valuta asing maupun rupiah. 4

Pengertian sukuk berbasis wakaf merupakan pengertian antara wakaf dengan sukuk. Dalam fikih, sukuk al-intifa' merupakan sukuk berbasis wakaf.Pernerbitan sukuk akan berdasar pada aset waakf yang digunakan. Dimana sukuk sebagai bukti hak milik suatuaset yang tidak dibagikan atas suatu aset atau kepemilikan atas proyek tertentu.

${ }^{1}$ Muhammad Iqbal Fasa, "Sukuk : Teori dan Implementasi", Li Falah jurnal studi ekonomi dan bisnis islam, vol 1, No. 1 (2016), h. 81

2Indah Purnamaati, "Perbandingan Sukuk dan Obligasi: Telaah dari Perspektif Keuangan dan Akuntansi”, jurnal akuntani Universitas Jember, h. 63

3Rina Antasari, Peny cahaya a., Dyah Martiwi, "Optimalisasi Peran Sukuk dalam menumbuhkan Sektor Riil di Indonesia", Jurnal Muamalah, vol 3, No. 1 (2017), h. 16-32

4Direktorat Pembiayaan Syariah, Direktorat Jenderal Pengelolaan Utang 


\section{Dasar Hukum Penerbitan Sukuk Negara / SBSN}

Dasar hukum bagi pemerintah untuk menerbitkan SBSN adalah :

1) Fatwa Nomor: 66/DSNMUI/III/2008. Waran Syariah.

2) Fatwa Nomor: 59/DSNMUI/V/2007. Obligasi Syariah Mudharabah Konversi.

3) Undang-undang Nomor : 19 tahun 2008 tentang Surat Berharga Syariah Negara

4) Fatwa DSN-MUI No. 32/DSNMUI/IX/2002. Akad Penerbitan Obligasi Syariah.

5) Fatwa No: 33/DSN-MUI/IX/2002. Obligasi Syariah Mudharabah.

6) Fatwa No: 20/DSNMUI/IV/2001. Usaha Halal Emiten

7) Fatwa Dewan Syariah Nasional Nomor 69/DSN-MUI/VI/2008 tentang Surat Berharga Syariah Negara.

8) Fatwa Nomor : 65DSN-MUI/III/2008. Hak Memesan Efek Terlebih Dahulu Syariah (HMETD Syariah)

9) Fatwa Dewan Syariah Nasional

10)Fatwa Dewan Syariah Nasional Nomor 71/DSN-MUI/VI/20o8 tentang Sale and Lease Back.

11) Fatwa Nomor: 76/DSNMUI/VI/2010. SBSN Ijarah Asset To Be Leased.

12) Fatwa Dewan Syariah Nasional Nomor 70/DSN-MUI/VI/2008 tentang Metode Penerbitan Surat Berharga Syariah Negara.

13) Fatwa Dewan Syariah Nasional Nomor 72/DSN-MUI/VI/2008 tentang Surat Berharga Syariah Negara Ijarah Sale and Lease Back.

14) Fatwa Nomor: 80/DSNMUI/III/2011. Penerapan Prinsip Syariah dalam Mekanisme Perdagangan Efek Bersifat Ekuitas di Pasar Reguler Bursa Efek.

15) Peraturan Bapepam dan LK Nomor IX.A.13.5

\section{Jenis-jenis Sukuk}

Melihat dari jenis akad yang digunakan dalam penerbitan sukuk, maka sukuk dapat dibedakan jenisnya sebagai berikut:

1) Sukuk Mudharabah adalah surat berharga yang menggunakan prinsip akad mudharabah. Mudharabah adalah akad kerjasama dengan skema profit sharing antara pemilik modal dan pengusaha.

2) Sukuk murabahah adalah surat berharga berdasarkan akad murabahah dimana murabahah ialah akad jual beli barang antara penjual dan pembeli dan mereka sepakat atas hasil yang diperoleh.

3) Sukuk musyarakah adalah suraat berharga berdasarkan prinsip musarakah dimana musyarakah adalah kemitraan antara dua orang atau lebih bersepakat untuk menggabungkan modal dan terlibat dalam pengelolaan usaha tersebut.

5Khoirudin, M.S.I.,"Sukuk Berbasis wakaf ;Suatu Kajian Hukum dan keuntungan Ekonomis di Indonesia" 
4) Sukuk salam adalah surat berharga yag menggunakan prinsip akad salam dimana akad salam adalah pembelian barang dilakukan dengan pembayaran dimuka dan barang akad didapat dikemudian hari,

5) Sukuk istishna adalah surat berharga yang berisi akad istishna dimana akad istishna ialah akad jual beli dengan bentuk pemesanan pembuatan barang dengan kriteria tertentu dan telaah disepakati.

6) Sukuk ijarah adalah surat berharga yang berakad ijarah dimana akad ini merupakan akad sewa menyewa terjadi pemindahan hak guna atas suatu barang atau jasa. ${ }^{6}$

\section{Perkembangan Sukuk Di Indonesia}

Pada tahun 2009, sukuk pertama kali diterbitkan oleh kementrian keuangan republik Indonesia dengan nama sukuk Negara Ritel o01 (SR 001). Sukuk retail ialah produk invstasi syariah yang ditawarkan oleh negara kepada warga negara Indonesia perorangan sebagai investasi yang mudah terjangkau, menguntungkan, dan aman. Seri SR o11 terakhir ditawarkan pada maret 2019. Sukuk negara sangat berperan pentingdalam peningkatan investasi pemerintah, pemberdayaan industri di dalam negeri, peningkatan pelayanan umum, danpembangunan infrastruktur negara.

Meningkatnya pasar keuangan syariah ditunjukkan dengan meningkatnya total akumulasi penerbitan sukuk korporasi. Sebelumnya tercatat sukuk korporasi sejumlah Rp 20,4 triliun di tahun 2016 dan menjadi Rp35,6 triliun di oktober 2018. Kemajuan perekonomian suatu negara tidak akan terjadi jika infrastuktur belum layak dan belum mencukupi.Indonesia masih jauh tertinggal jauh dari negara negara di kawasan ASEAN dalam hal pembangunan infrastruktur

Pembiayaan dan pasar keuangan syariah merupakan beberapa aspek yang digunakan untuk mendukung pembangunan nasional melalui dukungan ekonomi dan keuangan syariah.Diantara sumbernya yaitu dengan menerbitkan SBSN dan sukuk korporasi.7

\section{PEREKONOMIAN NASIONAL}

Ekonomi Indonesia pada tahun ini yang diprediksi PT Bank UOB Indonesia hanya mampu tumbuh 2,5 di tengah pandemi virus corona (covid19) yang berefek cukup besar terhadap sendi-sendi perekonomian nasional. Kepala Ekonom dan Riset UOB Indonesia hal ini disebabkan oleh pandemic Covid-19 yang menghantam konsumsi rumah tangga sebagai komponen terbesar dalam Produk Domestik Bruto (PDB) Indonesia.

Memperkirakan bahwa GDP (gross domestic product/PDB) akan konservatif sekitar 2,5\%, karena permintaan domestic akan paling terpukul, sedangkan ekspor dan impor cukup banyak dimatikan, lebih fokus pada peran untuk menghidupkan kembali, atau setidaknya mempertahankan private consumption (konsumsi swasta) serta bagaimana mengangani investasi.

\footnotetext{
${ }^{6}$ Angrum Pratiwi, dedy Mainata, dan Rizky Suci R., "Peran Sukuk Negara dalam Pembiayaan Infrastruktur", Al-Tijary jurnal eknomi dan bisnis islam, vol 2 no. 2 (2017), h. 155-176

7Fitrianto, "Sukuk Instrumen Pembiayaan Pemerintah untuk Pembangunan Negara", AtTaradhi: Jurnal Studi Ekonomi, Vol. X No. 1 (2019), h. 72-73
} 
Menyarankan pemerintah untuk dapat memberikan stimulus secara langsung pada beberapa sector yang paling terdampak oleh pandemi ini. Sektor-sektor ini yang memiliki andil besar dalam perekonomian, seperti pertambangan, manufaktur, konstruksi, serta ritel dan perdagangan, pada dasarnya adalah salah satu yang kami yakini paling benar-benar terkena dampaknya dibandingkan pertanian, komunikasi dan informasi, serta kesehatan manusia. Memprediksi ekonomi Indonesia akan kembali pulih pada 2021, dengan pertumbuhan mencapai 3,7\%.

Badan Pusat Statistik (BPS) tahun lali mencatat pertumbuhan ekonomi RI mendekati ke posisi tahun 2016 yang tumbuh 5,03\% tahun ini pertumbuhan ekonomi sebesar 5,02\%, Dan lebih lambat dari tahun-tahun sebelumnya, dan. Sebelumnya, Fitch Solutions Country Risk and Industry Research merilis outlook bulanan perekonomian ditengah pandemic covid-19. Dalam rilisnya tersebut, Fitch Solutions memprediksi perekonomian global dan juga Indonesia. Pertumbuhan ekonomi global di 2020 diprediksi berada diantara o\% dan -0,5\%. Fitch Solutions juga melihat perekonomian global baru mulai keluar dari resesi diakhir kuartal IV-2020. Diperkirakan perekonomian global mulai bisa keluar dari resensi diakhir kuartal-IV, dilihat dari resesi-resesi di akhir kuartal-IV, dilihat dari resesi-resesi yang terjadi sejak 1948 yang ratarata berlangsung selama 10 bulan hingga 12 bulan. Proyeksi tersebut diberikan dengan asumsi pademi Covid-19 mampu dihentikan dalam dua bulan ke depan. Adapun untuk Indonesia, mesti disebut menjadi yang 4,2\%, pada akhir tahun nilai tukar rupiah berada dikisaran Rp 16.750/US\$.

Prediksi pertumbuhan ekonomi Indonesia oleh Fitch Solutions tersebut terbilang cukup optimistis dibandingkan prediksi yang diberikan institusi lainnya. Bahkan Fitch Ratings, lembaga terpisah dari Fitch Solutions, dalam laporan berjudul"Global Economic Outlook-Crisis Update: 2 April 2020" memperkirkan PDB Indonesia tahun ini hanya tumbuh 2\%. Skenario pertumbuhan ekonomi saat konferensi, Skenario di kuartal I-2020 4,7\% kemudian dikuartal II-2020 1,1\% dan di kuartal III-2020 mencapai 1,3\% dan kemudian meningkat di kuartal IV-2020 2,4\%.8

\section{WABAH COVID 19}

Coronavirus adalah virus RNA strain tunggal positif, berkapsul dan tidak bersegmen. Coronavirus tergolong ordo Nidovirales, keluarga Coronaviridae. Struktur coronavirus membentuk struktur seperti kubus dengan protein $\mathrm{S}$ berlokasi dipermukaan virus. Protein $S$ atau spike protein merupakan salah satu protein antigen utama virus dan merupakan struktur utama untuk penulisan gen. Protein S ini berperan dalam penempelan dan masuknya virus kedalam sel host (interaksi protein $\mathrm{S}$ dengan reseptornya di sel inang). Coronavirus bersifat sensitif terhadap panas dan secara efektif dapat diinaktifkan oleh desinfektan mengandung klorin, pelarut lipid dengan suhu $5^{6^{\circ}}$ selama 30 menit, eter, alkohol,asam perioksiasetat, detergen non-ionik, formalin, oxidizing agent dan kloroform. Klorheksidin tidak efektif dalam menonaktifkan virus.

${ }^{8}$ Cnbn Indonesia, “ UOB: PDB RI Diprediksi Tumbuh 2,5\% di 2020 Gegara Corona”,dipaksa melalui https://www.cnbcindonesia.com/market/20200414093616-17-151694/uob-pdb-ridiprediksi-tumbuh-25-di-2020-gegara-corona. 
Coronavirus lebih banyak berada dihewan. Coronavirus lebih banyak menyebabkan infeksi virus kepada sapi, kuda, kucing dan ayam. Coronavirus disebut dengan virus zoonotik yaitu virus yang ditransmisikan dari hewan ke manusia. Banyak hewan liar yang dapat membawa patogen dan bertindak sebagai vektor untuk penyakit menular tertentu. Kelelawar, tikus bambu, unta dan musang merupakan sasaran utama yang biasa ditemukan untuk Coronavirus. Sumber utama dari coronavirus yaitu dari kelalawar untuk kejadian severe acute respiratorysyndrome (SARS) dan Middle East respiratory syndrome (MERS).

Coronavirus hanya bisa berkembangbiak melalui sel host-nya. Virus tidak bisa hidup tanpa sel host. Berikut siklus dari Coronavirus setelah menemukan sel host sesuai tropismenya. Pertama, penempelan dan masuk virus ke sel host diperantarai oleh Protein $S$ yang ada dipermukaan virus.5 Protein S penentu utama dalam menginfeksi spesies host-nya serta penentu tropisnya.. Pada studi SARS-CoV protein $\mathrm{S}$ berikatan dengan reseptor di sel host yaitu enzim ACE-2 (angiotensin-converting enzyme 2). ACE-2 dapat ditemukan pada mukosa oral dan nasal, nasofaring, paru, lambung, usus halus, usus besar, kulit, timus, sumsum tulang, limpa, hati, ginjal, otak, sel epitel alveolar paru, sel enterosit usus halus, sel endotel arteri vena, dan sel otot polos. Setelah berhasil masuk selanjutnya translasi replikasi gen dari RNA genom virus. Selanjutnya replikasi dan transkripsi dimana sintesis virus RNA melalui translasi dan perakitan dari kompleks replikasi virus. Tahap selanjutnya adalah perakitan dan rilis virus.

Setelah terjadi transmisi, virus masuk ke saluran napas atas kemudian bereplikasi di sel epitel saluran napas atas (melakukan siklus hidupnya). Setelah itu menyebar ke saluran napas bawah. Pada infeksi akut terjadi peluruhan virus dari saluran napas dan virus dapat berlanjut meluruh beberapa waktu di sel gastrointestinal setelah penyembuhan. Masa inkubasi virus sampai muncul penyakit sekitar 3-7 hari.

\section{Manifestasi Klinis}

Virus ini menimbulkan gejala dari ringan sampai berat. Gejala klinis utama yang muncul yaitu demam ( $\mathrm{suhu}>38^{\circ} \mathrm{C}$ ), batuk dan kesulitan bernapas. Selain itu dapat disertai dengan sesak memberat, fatigue, mialgia, gejala gastrointestinal seperti diare dan gejala saluran napas lain. Ada juga gejala timbul sesak dalam satu minggu. Pada kasus berat perburukan secara cepat dan progresif, seperti ARDS, syok septik, asidosis metabolik yang sulit dikoreksidan perdarahan atau disfungsi sistem koagulasi dalam beberapa hari. Ada beberapa pasien yang mengalami gejala ringan dan tidak disertai demam, Kebanyakan pasien memiliki prognosis baik, dan sebagian kecil dalam keadaan kritis dan meninggal. Berikut sindrom klinis yang dapat muncul jika terinfeksi. Berikut sindrom klinis yang dapat muncul jika terinfeksi:

1) Tidakberkomplikasi

Keadaan ini adalah keadaan yang ringan dan gejala yang muncul tidak spesifik. Gejala utama tetap muncul seperti demam, batuk, dapat disertai dengan nyeri tenggorok, kongesti hidung, malaise, sakit kepala, dan nyeri otot. 
Harus diperhatikan pasien yang sudah monopause dan immunocompromises presentasi gejala menjadi tidak khas atau atipikal. Ditemui beberapa kasus tidak disertai dengan demam dan gejala relative ringan. Pada kondisi ini pasien tidak memiliki gejala komplikasi diantaranya dehidrasi, sepsis atau napas pendek.

2) Pneumoniaringan

Gejala utama yaitu seperti batuk, dan sesak. Namun tidak ada tanda pneumonia berat. Pada anak-anak dengan pneumonia tidak berat ditandai dengan batuk atau susahbernapas

3) Pneumonia berat pada pasien dewasa

Gejala yang muncul seperti demam atau curiga infeksi saluran napas. Tanda yang muncul yaitu takipnea (frekuensi napas: > 30x/menit), distress pernapasan berat atau saturasi oksigen pasien $<90 \%$ udara luar.

\section{Penegakan Diagnosis}

Pada anamnesis gejala yang dapat ditemukan yaitu, tiga gejala utama: demam, batuk kering (sebagian kecil berdahak) dan sulit bernapas atau sesak.

A. Pasien dalam pengawasan atau kasus suspek/possible, seseorang yangmengalami:

1. Demam $\left(\geq 38^{\circ} \mathrm{C}\right)$ atau riwayat demam

2. Batuk atau pilek atau nyeritenggorokan

3. Pneumonia ringan sampai berat berdasarkan klinis dan/atau gambaran radiologis. (pada pasien immunocompromised presentasi kemungkinan atipikal) dan disertai minimal satu kondisi sebagai berikut:

a. Memiliki riwayat perjalanan ke Tiongkok atau wilayah/ negara yang terjangkit* dalam 14 hari sebelum timbul gejala

b. petugas kesehatan yang terinfeksi setelah merawat pasien ISPA dengan gejala berat dan tidak melihat riwayat berpergian dan tempat tinggal.

B. Pasien infeksi pernapasan akut dengan tingkat ringan sampai berat dan dalam kurung waktu 14 hari sebelum terjadi gejala:

1. Riwayat pernah berkontak erat dengan pasien yang terinfeksi

2. Pernah kontak dengan hewan yang menularkan virus

3. Bekerja atau megunjungi suatu tempat layanan kesehatan yang terkonfirmasi atau probable infeksi COVID-19 di Tiongkok atau wilayah yang terjangkit .

4. Pernah berkunjung ke wuhan dan mengalami gejala demam (suhu $\geq 380 \mathrm{C}$ )

C. Orang dalamPemantauan

Seseorang yang Pernah berkunjung ke tempat yang terkonfirmasi virus dengan menimbulkan gejala demam/ demam tanpa pneuomonia :

1. Kontak erat dengan kasus terkonfirmasi COVID-19.

2. Bekerja atau mengunjungi suatu tempat layanan kesehatan yang 
terdeteksi covid-19 di Tiongkok atau wilayah yang terjangkit.

3. Pernah kontak dengan hewan yang sudah terdeketsi bisa menularkan virus

4. Kasus probable

5. Pasien yang masih belum bisa disimpulkan bahwa terkonfirmasi atau seseorang dengan hasil positif terpapar Covid-19.

6. Kasus terkonfirmasi

7. Seseorang yang secara laboratorium terkonfirmasi COVID-19.

\section{Pemeriksaan Penunjang}

a. Pemeriksaan radiologi: foto toraks, CT-scan toraks, USG toraks. Pada pencitraan dapat menunjukkan: opasitas bilateral, konsolidasi subsegmental, lobar atau kolaps paru atau nodul, tampilangroundglass.

b. Pemeriksaan spesimen saluran napas atas dan bawah

1. Saluran napas atas dengan swab tenggorok (nasofaring danorofaring)

2. Saluran napas bawah (sputum, bilasan bronkus, BAL, bila menggunakan endotrakeal tube dapat berupa aspirat endotrakeal

c. Bronkoskopi

d. Pungsi pleura sesuai kondisi

e. Pemeriksaan kimia darah

f. Biakan mikroorganisme dan uji kepekaan dari bahan saluran napas (sputum, bilasan bronkus, cairan pleura) dan darah 26,27 Kultur darah untuk bakteri dilakukan, idealnya sebelum terapi antibiotik. Namun, jangan menunda terapi antibiotik dengan menunggu hasil kultur darah)

g. Pemeriksaan feses dan urin (untuk investasigasi kemungkinan penularan).

\section{Tatalaksana Umum}

a. Semua kasus diisolasi sesuai dengan gejala yang muncul

b. Implementasi pencegahan dan pengendalian infeksi (PPI)

c. Serial foto toraks untuk menilai perkembangan penyakit

d. Suplementasi oksigen

e. Kenali kegagalan napas hipoksemia berat

f. Terapi cairan

g. Pemberian antibiotik empiris

h. Terapisimptomatik

i. Pemberian kortikosteroid sistemik tidak rutin diberikan pada tatalaksana pneumonia viral atau ARDS selain ada indikasi lain.

j. Observasi ketat

k. Pahami komorbidpasien 
Pada kondisi saat ini belum adanya penelitian dan tatalaksana antiviral untuk infeksi Coronavirus yang teruji efektif. Dan juga belum ada vaksin untuk mencegah Coronavirus ini. 9

\section{DAMPAK SUKUK BAGI PEREKONOMIAN NASIONAL}

Seiring berjalanya waktu, sukuk di Indonesia telah mengalami peningkatan seperti dengan data yang terlihat di statistik OJK. Penerbitan SBSN atau sukuk ini bertujuan untuk menutup defisit anggaran Negara.

\section{Grafik 1.}

Perkembangan Sukuk Korporasi tahun 2015-2020

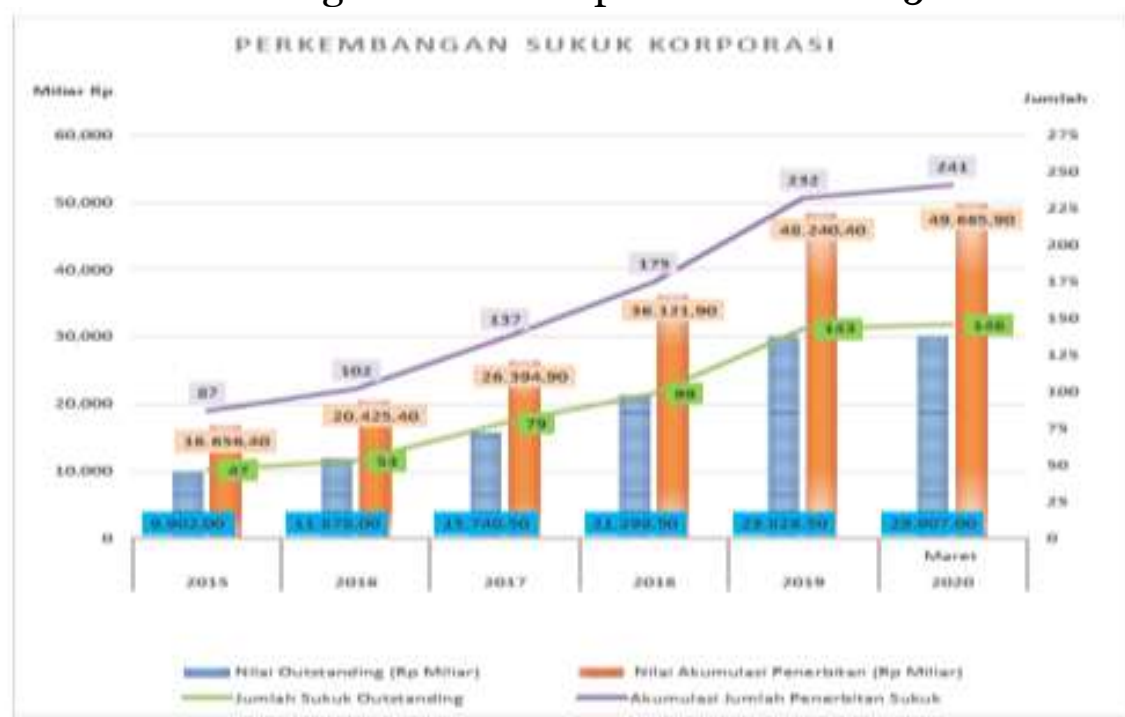

Sumber: Statistik Sukuk Maret 2020, diakses melalui https:ojk.go.id

Dapat dilihat dari tabel statistik tersebut bahwa dari tahun 2015 sampai maret 2020 outstanding sukuk terus mengalami peningkatan.Peningkatan outstanding terbanyak terjadi pada tahun 2018 yaitu dari 53 sukuk outstanding menjadi 79 sukuk outstanding atau terjadi peningkatan sebesar 20 jumlah sukuk outstanding. Sementara itu peningkatan terendah terjadi pada bulan maret 2020 yaitu jumlah outstanding pada 2019 sebesar 143 sementara di maret 2020 hanya terjadi peningkatan 3 poin menjadi sebesar 146 outstanding sukuk yang beredar. Outstanding sukuk yang beredar ini meliputi sukuk ijarah, mudharabah, dan wakalah.

Penerbitan sukuk ini bertujuan untuk mendukung perkembangan industri pasar modal syariah yang akan digunakan sebagai modal pendanaan untuk membiayai perkembangan usaha mikro makro dan pembangunan infrastruktur bagi negara. ${ }^{10}$ Sukuk memiliki kelebihan yang tidak dimiliki oleh produk investasi lainnya yaitu resiko yang lebih rendah. Dapat dikatakan bahwa

9 Yuliana, "Corona virus diseases (Covid-19); Sebuah tinjauan literatur", Fakultas Kedokteran Universitas Lampung, Volume 2, Nomor 1 (2020).

10 Nurlaili Adkhi Rizfa Faiza, Shafiyatun Shafiyatun, "Pengaruh Nilai Outstanding Sukuk Korporasi Terhadap Produk Domestik Bruto (PDB) Indonesia" dalam eL-Qist: Journal of Islamic Economics and Business (JIEB) Vol. 8 No. 1 April (2018). 
sukuk adalah investasi yang aman. Penerbitan sukuk ini juga berfungsi untuk mengendalikan jumlah uang yang beredar sehingga dapat mengatasi masalah inflasi.

\section{Dampak Covid 19 Bagi Perekonomian Nasional}

Sejak Desember 2019, perekonomian didunia telah digemparkan oleh wabah covid 19 yang berasal dari wuhan, Cina. Mengingat Cina adalah pemenang dari perang dagang yang terjadi antara Cina dan Amerika dan sempat memanas beberapa bulan sebelumnya tentu wabah ini seolah menjadi boomerang sendiri bagi Cina. Perang dagang tersebut telah memberikan dampak negatif bagi perekonomian didunia ditambah dengan serangan wabah covid ini seakan menjadi serangan yang bertubi-tubi bagi perekonomian di dunia, termasuk Indonesia.

Selama lima tahun terakhir, Tiongkok telah menjadi mitra dagang Indonesia. Hal ini tentu mempengaruhi Indonesia ketika perekonomian di China lumpuh. Terlebih lagi penyebaran virus covid-19 yang sangat cepat ke Negara-negara lainya termasuk Indonesia juga memperparah keadaan ekonomi. Pasalnya pemerintah telah mengeluarkan sejumlah kebijakan yang digunakan untuk memutus rantai penyebaran virus seperti pembatasan social dan penutupan sejumlah perusahaan yang membuat masyarakat membatasi tingkat konsumsinya karena minimnya pemasukan atau bahkan sama sekali tidak ada pemasukan sementara kebutuhan sehari-hari terus berjalan. Sejumlah kebijakan dikeluarkan untuk meringankan beban rakyat termasuk pemberian subsidi listrik dan pemberian bantuan tunai setiap bulanya. Hal ini membuat anggaran Negara yang terus berkurang sementara tidak ada pemasukan yang membuat Negara melakukan hutang dalam jumlah besar termasuk meluncurkan global kupon bon guna menyetabilakan keadaan perekonomian di Indonesia. ${ }^{11}$

\section{Perbandingan Perekonomian Nasional Sebelum dan Saat Terjadi Pandemi Covid 19}

Sebelum adanya wabah covid 19, Indonesia sudah pernah mengalami kemerosotan ekonomi yaitu pada tahun 1997, 1998 sampai 1999 saat terjadi krisis moneter akibat anjloknya harga minyak di dunia. Saat ini kelesuan ekonomi juga tengah terjadi akibat menyebarnya covid 19 awal tahun baru 2020 yang berasal dari Cina.Covid 19 sendiri mulai melanda di Indonesia pada bulan maret 2020 dan terus mengalami peningkatan hingga sekarang.Berbagai upaya dilakukan pemerintah untuk mengendalikan penyebaran virus ini dan menyetabilkan ekonomi.Pengendalian virus covid 19 dilakukan mulai dari pemberlakuan semi lockdown hingga PSBB sementara penyetabilan ekonomi dilakukan dengan penurunan suku bunga acuan, pemberian subsidi hingga peluncuran kupon global bon.

${ }^{11}$ Ridho Syukra, "pasca covid-19, Laju Pertumbuhan Ekonomi Indonesia Tak Langsung Pulih", dipaksa melalui https://investor.id/business/pasca-covid19-laju-pertumbuhan-ekonomiindonesia-tak-langsung-100-pulih. 
Di tahun-tahun sebelumnya, lebih tepatnya sebelum terjadi pandemic Covid 19, perekonomian dunia juga sempat terusik akibat bocornya tangki minyak di Saudi mengingat Saudi adalah pemasok minyak terbesar di dunia, namun hal tersebut dapat dikendalikan karena cadangan minyak di Amerika sudah mencukupi. Terlebih bocornya tangki minyak tidak begitu bereaksi terhadap perekonomian Indonesia mengingat Indonesia sendiri adalah penghasil minyak bumi.

Menurut kepala badan pusat statistic pertumbuhan ekonomi Indonesia pada kuartal III 2019 sebesar 5,02\% secara tahunan. Angka ini sebenarnya melambat dibandingkan kuartal sebelumnya sebesar 5,05\% maupun periode yang sama di tahun lalu yaitu sebesar 5,17\%. Sementara itu pada kuartal I/2020 ekonomi Indonesia melambat 2,97\% (yoy). Pada triwulan I/2019 ekonomi Indonesia masih tumbuh 5,07\%. Diperkirakan pada kuartal II/2020 perekonomian Indonesia akan terus merosot, bahkan akan terancam resesi. Perlambatan pertumbuhan ekonomi ini tidak hanya dialami oleh indonesia namun juga negara-negara di dunia yang terkena imbas dari wabah covid 19. Hal ini masih lebih baik dibanding Negara lain, misalnya Amerika Serikat dan Singapura yang pertumbuhan ekonominya hanya sebesar $0,3 \%$ dan $-2,2 \%$. Hongkong dan Uni Eropa sebesar -8,9\% dan -2,7\%. Dari hal tersebut dapat diketahui bahwa pertumbuhan ekonomi Indonesia cukup stabil dan terkendali.

\section{Dampak Sukuk Bagi Perekonomian Saat Terjadi Pandemi Covid 19}

Pada tanggal 24 maret 2020 pemerintah menawarkan utang berupa lelang SBSN atau sukuk. Dari lelang tersebut pemerintah mendapatkan dana sebesar 6,6 triliun. Hal tersebut masih kurang dari target yang ditetapkan namun angka ini cukup tinggi mengingat kelesuan ekonomi yang terjadi saat ini. Dana yang terkumpul dari lelang itu akandigunakan pemerintah untuk pemenuhan kebutuhan APBN. Sukuk memberikan sarana bagi masyarakat untuk menginvestasikan dananya sehingga bermanfaat bagi negara dan bermanfaat bagi kemakmuran masyarakat. Sukuk bisa dimanfaatkan oleh Lembaga Keuangan Syariah untuk sarana pemenuhan likuiditas saat berkelebihan dana, mengingat pembiayaan kepada masyarakat tersendat akibat roda perekonomian terhambat oleh akibat virus. Hal ini menjadikan Lembaga keuangan syariah berpotensi memiliki kelebihan dana akibat serapan pembiayaan yang terbatas. Pada situasi kurs rupiah yang melemah akibat wabah, maka sukuk memberikan dorongan untuk menguatkan industri keuangan. APBN yang terpenuhi dari sumber dana sukuk, dengan mudah kemudian disalurkan ke dunia usaha melalui kredit khusus yang dibuat semurah mungkin. Hal ini bertujuan untuk mengurangi dampak PHK yang banyak terjadi akibat perusahaan kekurangan cashflow dan likuiditas keuangan.Dari pemaparan tersebut dapat ditarik kesimpulan bahwa sukuk cukup memberi dampak bagi pertumbuhan ekonomi nasional melalui pergerakan ekonomi masyarakat yang sempat stagnan akibat covid 19.

\section{KESIMPULAN}

Sukuk memberikan dampak bagi pertumbuhan perekonomian nasional. Sukuk menjadi salah satu bentuk investasi yang memiliki resiko kecil sehingga cukup diminati oleh sebagian besar badan usaha. Hal ini tepat dilakukan pada 
saat Wabah covid 19 terjadi dan memiliki efek pada tersendatnya pertumbuhan perekonomian nasional. Pertumbuhan ekonomi melambat 2,97\% akibat diberlakukannya beberapa kebijakan untuk mencegah penularan covid 19. Perekonomian sebelum terjadi pandemi covid 19 cukup stabil dan mengalami penurunan ketika pandemi covid 19 mulai muncul. Hal tersebut terjadi karena diberlakukanya segala kebijakan untuk mencegah penyebaran covid 19, termasuk kebijakan lockdown. Sukuk menjadi sumber dana bagi pemerintah untuk membiayai pembangunan, sehingga menciptakan lapangan kerja baru bagi masyarakat dalam jangka panjangnya. Sukuk memberikan kemanfaatan bagi likuiditas lembaga keuangan syariah akibat dampak covid 19, dan juga sarana investasi bagi masyarakat.

\section{DAFTAR PUSTAKA}

Abdul Wahid, Nazaruddin.Sukuk Memahami dan Membedah Obligasi Pada Perbankan Syariah. Yogyakarta: Ar-Ruzz Media. 2010.

Affandi Mahfuds, Ahmad. Pasar dan Instrument Keuangan islam. Edisi II. Cet I. Tangerang Selatan: Universitas Terbuka, 2014.

Angrum, Pratiwi, Dedy Mainata dan Rizky Suci R.. "Peran Sukuk Negara dalam Pembiayaan Infrastruktur" dalam Al-Tijary jurnal eknomi dan bisnis islam, vol 2 no. 2, 2017.

Antonio. Muhamad Syafi'I. Bank Syariah Dari Teori Ke Praktek. Jakarta: Gema Insani, 2001.

Cnbc Indonesia. (2020, 14 april). “ UOB: PDB RI Diprediksi Tumbuh 2,5\% di 2020 Gegara Corona”. Diakses pada tanggal 04 Mei 2020 dalam https://www.cnbcindonesia.com/market/20200414093616-17151694/uob-pdb-ri-diprediksi-tumbuh-25-di-2020-gegara-corona

Faiza, Nurlaili Adkhi Rizfa dan Shafiyatun Shafiyatun, "Pengaruh Nilai Outstanding Sukuk Korporasi Terhadap Produk Domestik Bruto (PDB) Indonesia" dalam eL-Qist: Journal of Islamic Economics and Business (JIEB) Vol. 8 No. 1 April (2018)

Fasa, Muhammad Iqbal. "Sukuk : Teori dan Implementasi" dalam Li Falah Jurnal Studi Ekonomi dan Bisnis Islam, No. 1 Vol. I. 2016.

Fitrianto, Fitrianto. "Sukuk Instrumen Pembiayaan Pemerintah untuk Pembangunan Negara” dalam At-Taradhi: Jurnal Studi Ekonomi, Vol. X No. 1. 2019.

Hannoeriadi, Ivan, Deni Lubis. "Pengaruh Variabel Makroekonomi terhadap Pertumbuhan Sukuk korporasi di Indonesia” dalam Jurnal Al-Muzara'ah Institut Pertanian Bogor, Vol.5 No.1. 2017. 
Heyka, Mohamad.Tuntunan dan Aplikasi Investasi Syariah. Jakarta: PT. Elex Media Komputindo, 2012.

http://www.ojk.go.id/statistik-sukuk-mei-2020. diakses pada tanggal 5 mei 2020.

http://www.kemenkeu.go.id/. Diakses pada tanggal 5 mei 2020.

Hulwati. "Investasi Sukuk: Persprektif Ekonomi Syariah" dalam JEBI (Jurnal Ekonomi dan Bisnis Islam UIN Sunan Bonjol) Vol. II No. 1. 2017.

Ilyas, R."Konsep Pembiayaan Dalam Bank Syariah.” dalam Jurnal Penelitian. Vol 9 , No 1. Februari 2015.

Khoirudin, M.S.I.,"Sukuk Berbasis wakaf ;Suatu Kajian Hukum dan keuntungan Ekonomis di Indonesia, UIN Raden Intan

Rina Antasari, Peny cahaya a., Dyah Martiwi, 2017, "Optimalisasi Peran Sukuk dalam menumbuhkan Sektor Riil di Indonesia" dalam Jurnal Muamalah, No. 1 Vol. 3.

Mervyn K. Lewis dan Latifa M. Algaoud.Perbankan Syariah : Prinsip,Praktik dan Prospek. Jakarta: PT.Serambi Ilmu Semesta, 2007.

Novinawati. "Akad Dan Produk Perbankan Syariah" dalam Fitrah: Jurnal Fakultas Ekonomi dan Bisnis Islam IAIN Padangsidimpuan, vol. 8 no. 2, 2014.

Nazaruddin abdul wahib. Sukuk memahami \& membedah obligasi pada perbankan syariah. Yogyakarta: Ar-Ruzz Media. 2010.

Syukra, Ridho. (2020, 1 Mei)._"pasca covid-19, Laju Pertumbuhan Ekonomi Indonesia Tak Langsung Pulih". Diakses pada tanggal o5 Mei 2020 dalam https://investor.id/business/pasca-covid19-laju-pertumbuhanekonomi-indonesia-tak-langsung-10o-pulih

Sutedi, Adrian.Aspek Hukum Obligasi dan Sukuk. Cet II. Jakarta: Sinar Grafika, 2009

Purnamaati, Indah. "Perbandingan Sukuk dan Obligasi (Telaah dari Perspektif Keuangan dan Akuntansi)" dalam Jurnal akuntani Universitas Jember.

Susilo, Edi. Analisis Pembiayaan Dan Risiko Perbankan Syariah. Yogyakarta: Pustaka Pelajar, 2017.

Susila, Jaka."Fiduciary Dalam Produk-Produk Perbankan Syariah" dalam Jurnal al-ahkam:jurnal ilmu syariah dan hukum IAIN Surakarta, vol. 1 no. 2, 2016.

Yuliana, Yuliana. "Corona virus diseases (Covid-19); Sebuah tinjauan literatur”. Dalam Jurnal Fakultas Kedokteran Universitas Lampung. Vol. 2, No. 1. 2020. 